This item was submitted to Loughborough's Research Repository by the author.

Items in Figshare are protected by copyright, with all rights reserved, unless otherwise indicated.

\title{
Utility of tris(4-bromopyridyl) europium complexes as versatile intermediates in the divergent synthesis of emissive chiral probes
}

PLEASE CITE THE PUBLISHED VERSION

http://dx.doi.org/10.1039/c4dt00253a

\section{PUBLISHER}

(c) The Royal Society of Chemistry

\section{VERSION}

AM (Accepted Manuscript)

\section{PUBLISHER STATEMENT}

This work is made available according to the conditions of the Creative Commons Attribution-NonCommercialNoDerivatives 4.0 International (CC BY-NC-ND 4.0) licence. Full details of this licence are available at: https://creativecommons.org/licenses/by-nc-nd/4.0/

\section{LICENCE}

CC BY-NC-ND 4.0

\section{REPOSITORY RECORD}

Butler, Stephen J., Martina Delbianco, Nicholas H. Evans, Andrew T. Frawley, Robert Pal, David Parker, Robert S. Puckrin, and Dmitry S. Yufit. 2019. "Utility of Tris(4-bromopyridyl) Europium Complexes as Versatile Intermediates in the Divergent Synthesis of Emissive Chiral Probes". figshare. https://hdl.handle.net/2134/18760. 


\title{
Utility of tris(4-bromopyridyl) europium complexes as versatile intermediates in the divergent synthesis of emissive chiral probes
}

Stephen J. Butler ${ }^{\text {a }}$, Martina Delbianco ${ }^{a}$, Nicholas H. Evans ${ }^{\text {a,b }}$, Andrew T. Frawley ${ }^{\text {a }}$, Robert Pal a , David Parker*, Robert S. Puckrin ${ }^{\text {a }}$ and Dmitry S. Yufit ${ }^{\text {a }}$

a) Department of Chemistry, Durham University, South Road, Durham DH1 3LE, UK;

b) Department of Chemistry, Lancaster University, Lancaster, LA1 4YB, UK.

Email:david.parker@dur.ac.uk

\begin{abstract}
The synthetic utility of europium complexes with three coordinated 4-bromopyridyl groups for chromophore elaboration has been assessed in palladium-catalysed Sonogashira coupling reactions, and in copper(I) mediated click reactions of the triazide derivative, generated in situ. The crystal structure of the Eu complex of a $p$-OMe-phenyl substituted triazole at $100 \mathrm{~K}$ is reported in which the pendant triazole sensitising moieties interdigitate in the solid-state lattice. The triazole complex can be separated into $\Delta$ and $\Lambda$ enantiomers by chiral HPLC but is weakly emissive in methanol $\left(\varepsilon 5.5 \mathrm{mM}^{-1} \mathrm{~cm}^{-1} ; \lambda_{\mathrm{exc}} 320 \mathrm{~nm} ; \phi 0.2 \%\right)$, contrasting with a set of four alkynyl-aryl derivatives which are one thousand times brighter and absorb strongly with broad absorption maxima in the range 332 to $360 \mathrm{~nm}$. An enantiopure europium complex gives an intense CPL signal in solution that is the strongest yet reported.
\end{abstract}

\section{Introduction}

In the synthesis of metal coordination complexes, it is most common to introduce the metal centre in the final step. This approach is often used in order to simplify the preparation and purification of ligand intermediates in non-polar media, and because many functionalisation reactions involve rather harsh reactions conditions under which dissociation of the metal ion may occur, e.g. extremes of $\mathrm{pH}$. An alternative strategy seeks to identify a robust metal coordination complex that can serve as a late intermediate in the synthesis of the target 
complex, bearing an appropriate functional group (or groups) that can be modified or elaborated under relatively mild conditions. Examples of this divergent approach can be found in several different areas of coordination chemistry with kinetically inert metal complexes. For example, Williams has used a variety of Suzuki coupling reactions with iridium(III) complexes bearing aryl bromide functionality, either to extend ligand conjugation or create multimeric systems. ${ }^{1,2}$ In lanthanide systems, modular syntheses of heterometallic complexes have been devised by using kinetically stable complexes of heptadentate and octadentate ligands, in a series of Ugi, $\mathrm{Pd}(0)$ or $\mathrm{Cu}(\mathrm{I})$ catalysed 'click' reactions. ${ }^{3-6}$ There are also many examples to be found in contrast agent research, where Gd complexes of octadentate ligands, with between one and four peripheral functional groups, serve as intermediates in the synthesis of higher molecular weight conjugates. Typically, these examples involve amide bond formation or coordination of a pendant chelate to a second metal ion. ${ }^{7-10}$

In the development of emissive lanthanide optical probes, it is particularly attractive to devise a kinetically stable and synthetically versatile precursor complex that can be modified easily, as this approach allows systematic changes in the structure of the sensitising chromophore to be undertaken at the end of the synthesis. This divergent strategy contrasts with the linear synthetic approaches usually adopted, wherein a single sensitising moiety is engineered into the ligand at the beginning of the synthesis. It allows systematic variations to be made that permit an optimisation of the absorption properties ( $\lambda_{\max }$ and $\varepsilon$ ), whilst retaining the common coordination environment about the lanthanide ion that primarily determines the chemical stability of the complex and its resistance to excited state quenching.

Owing to their line-like emission spectra, large Stokes' shifts and long-lived excited states, emissive lanthanide complexes are proving to be excellent probes of biological systems and fluids. ${ }^{11-19}$ Recently, a series of very bright $\mathrm{Eu}(\mathrm{III})$ phosphinate and carboxylate complexes has been reported containing pyridyl-alkynyl-aryl chromphores (Fig. 1). ${ }^{12}$ These bright complexes $\left(\varepsilon \sim 60 \mathrm{mM}^{-1} \mathrm{~cm}^{-1}\right.$ and $\phi_{e m}$ in the range 20 to $\left.50 \%\right)$, possess broad absorption bands with $\lambda_{\max } \sim 330$ to $350 \mathrm{~nm}$, meaning they can be excited using lasers or light emitting diodes at $337,355,365$ or $375 \mathrm{~nm}$, as required for use in cellulo. The peripheral functionalization of a second generation of complexes, has allowed for the staining of specific cell organelles, and time-resolved microscopy and spectral imaging studies have 
been investigated. ${ }^{13}$ A simple retrosynthetic analysis of these systems (Fig. 1) reveals that the tris(4-bromopyridine) complex, [Eu.L $\left.{ }^{1}\right]$ can serve as a common late intermediate and be used to prepare a wide range of analogues, via palladium-catalysed $\mathrm{C}-\mathrm{C}$ bond forming reactions to $\mathrm{sp}^{2}$ or $\mathrm{sp}$ hybridised carbon centres.

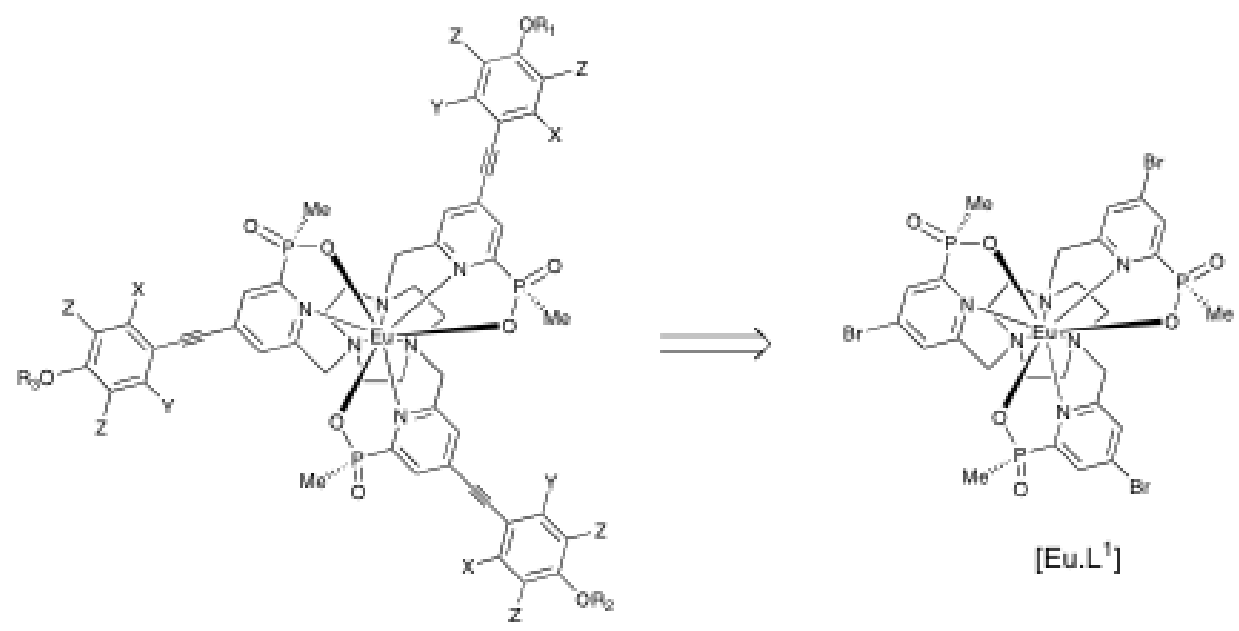

Figure $1 \quad$ Retrosynthetic analysis of tris-pyridyl-alkynyl-aryl phosphinate complexes

To be used efficiently as stains and probes the complexes should be amenable to structural modification, for example to include substituents of varying steric demand, charge centres and/or hydrogen bond donors/acceptors, to tune affinity and gain selectivity. The triazoleforming copper-catalysed alkyne-azide cycloaddition (CuAAC) reaction is an attractive chemical reaction that allows such synthetic control, due to its wide applicability. ${ }^{20}$ The tribromo-complex, [Eu.L ${ }^{1}$ ] can be easily transformed into the corresponding triazide, owing to the enhanced electrophilicity of the $\mathrm{C}-\mathrm{Br}$ bond. Interestingly, only two examples of lanthanide complexes incorporating pyridyl-triazole-aryl acyclic chelating ligands appear in the literature (Fig. 2). ${ }^{21,22}$ Critically, each report states that the complexes have an absorption wavelength of $320 \mathrm{~nm}$ or more and, in the latter example, sensitised excitation of Eu(III) has been demonstrated. 

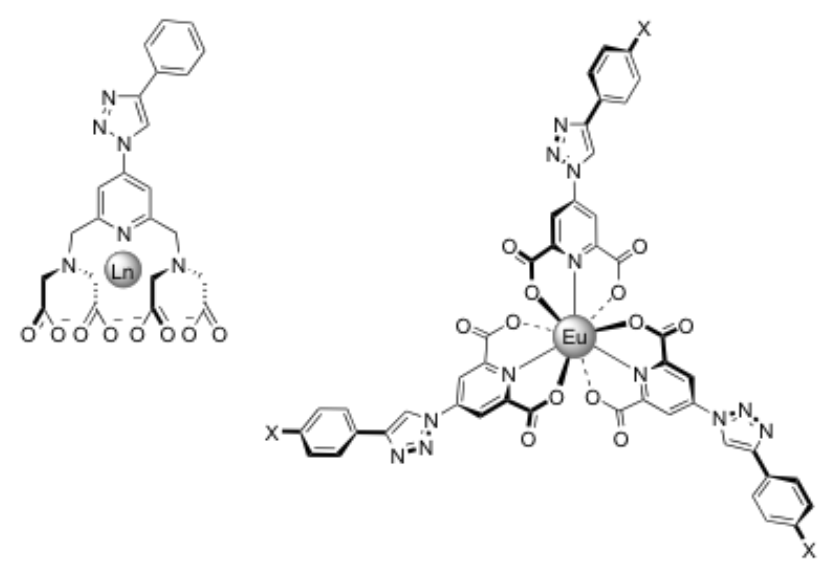

Figure 2

Selected reported pyridyl-triazole-aryl lanthanide complexes ${ }^{21,22}$

In this work, we exemplify the synthetic utility of $\left[\mathrm{Eu} . \mathrm{L}^{1}\right]$ in a set of Sonogashira reactions that allows the synthesis of four different aralkynyl substituted complexes. In addition, we show that substitution of pyridyl-alkynyl-aryl chromophores by pyridyl-triazole-aryl moieties allows the creation of a lanthanide complex that can also be excited at the wavelengths used in cellular studies. In addition to solution phase characterisation, a single crystal structure determination is reported of the triazole complex, $\left[\mathrm{Eu} . \mathrm{L}^{2}\right]$, as well as the characterisation of a Eu complex, $\left[\mathrm{Eu} . \mathrm{L}^{6}\right]$, by circularly polarised luminescence that reveals it to be the brightest chiral complex yet observed; it possesses the strongest total CPL signal that has been measured.

\section{Results and Discussion}

Synthesis and characterisation of a triazole complex

A tris-pyridyl-triazole-anisole $\mathrm{Eu}(\mathrm{III})$ complex was prepared in a two-step, one-pot sequence from the recently reported tris-(4-bromopyridyl) complex, [Eu.L $\left.{ }^{1}\right]$ (Scheme 1). ${ }^{23}$ Substitution of the bromide by azide was carried out at room temperature in DMF using excess sodium azide. The reaction was quantitative and generated the intermediate triazide complex, which was used directly without separation of the excess sodium azide. The second step, the $\mathrm{Cu}$ catalysed "click" cycloaddition occurred under mild conditions in aqueous DMF, requiring the addition of sub-stoichiometric amounts of the accelerant, tris[(1-benzyl-1H-1,2,3-triazol4-yl)methyl]amine (TBTA). ${ }^{1}$

\footnotetext{
${ }^{1}$ Full conversion of the triazide complex to the product tris-triazole was observed by LC-MS. The low isolated yield is associated with the efficiency of the chromatographic purification steps.
} 

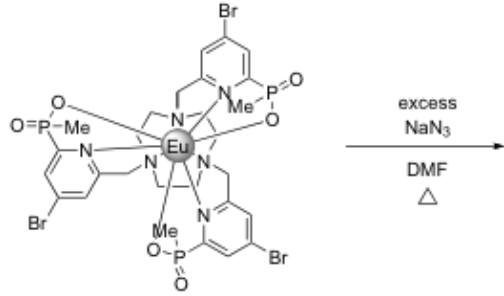
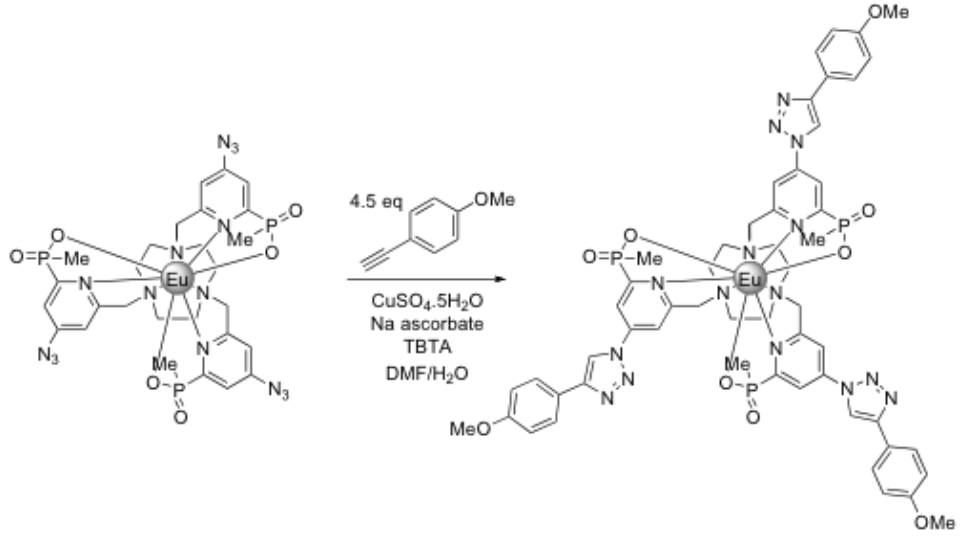

Scheme 1

Synthesis of the trispyridyl-triazole-anisole Eu(III) complex, [Eu.L $\left.{ }^{2}\right]$

The complex was characterized by ${ }^{1} \mathrm{H}$ and ${ }^{31} \mathrm{P}$ NMR spectroscopy and ES mass spectrometry (ESI). The presence of a single peak in the ${ }^{31} \mathrm{P}$ NMR spectrum is consistent with the threefold complex symmetry in solution. In addition, very small single crystals were grown by evaporation of a water/methanol solution of the complex, and were suitable for X-ray crystallographic structure determination using synchrotron radiation (Fig. 3). Even after taking account of the disorder present in the structure, there is a clear loss in the $C_{3}$ symmetry of the complex in the solid state, as was observed in the structure of a closely related europium tris-alkynyl complex, in which P-phenyl substituents replace the P-methyl groups in $\left[\mathrm{Eu} . \mathrm{L}^{2}\right] .{ }^{12}$

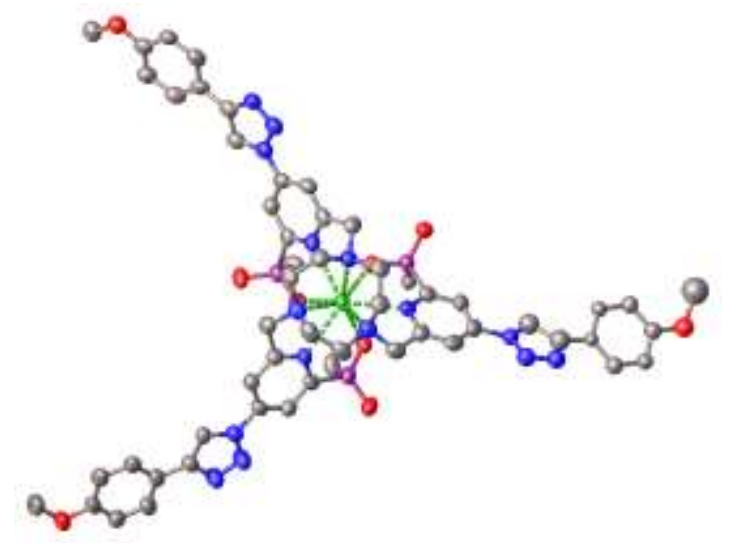

Figure 3 The molecular structure of [Eu.L $\left.{ }^{2}\right]$ (ellipsoids are drawn at the $50 \%$ probability level; one of the disordered components and the H atoms are omitted for clarity: CCDC 982687). 

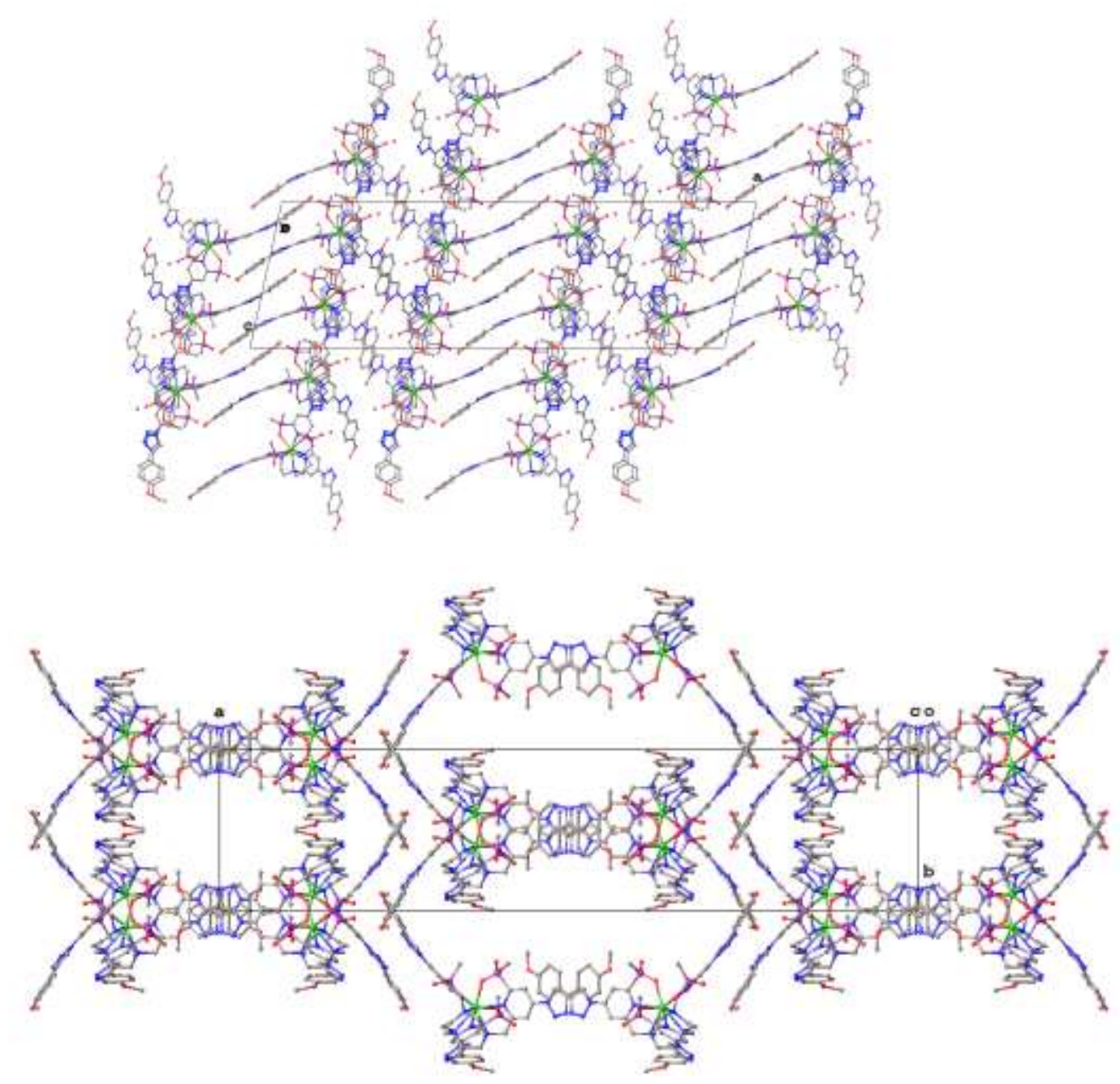

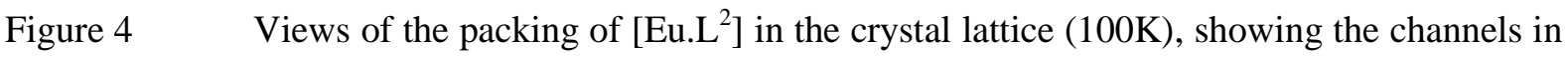
the lattice arising from $\pi$-stacking of the aryl-substituted chromophores.

Two "arms" of the molecule [Eu.L $\left.L^{2}\right]$ are essentially flat (the absolute values of minimal torsion angles around the bonds, connecting aromatic rings, are less than $8^{\circ}$ ) while the third one is disordered over two positions and noticeably twisted - the average torsion angles between pyridyl/triazole and triazole/anisole rings are ca. $12^{\circ}$ and $33^{\circ}$ respectively. Such a difference in the conformation of the pendant arms is probably induced by a different crystal environment. Indeed, the two flat "arms" form extensive $\pi \ldots \pi$ interactions between them, while the disordered arm is linked to adjacent molecules only by weaker C-H.. $\pi$ and C-H...O interactions, which operate independently of each other. The combination of all these intermolecular interactions results in a quite unusual crystal packing, characterized by the presence of wide channels along the crystallographic $c$-direction (Fig. 4: lower). The size of the channels is approximately $13.5 \AA$ x $7.5 \AA$ and each one contains a significant number of 
severely disordered solvent molecules. This phenomenon partially explains the poor diffracting properties of the crystals of $\left[\mathrm{Eu}_{\mathrm{L}} \mathrm{L}^{2}\right]$, for which the synchrotron radiation source (Diamond) was used to aid data acquisition.

Photophysical characterisations were subsequently undertaken in methanol. ${ }^{2}$ Critically, the absorption spectrum reveals that the complex has a broad absorption band at $320 \mathrm{~nm}$, which allows for excitation of the complex at wavelengths $>340 \mathrm{~nm}$. The europium emission spectrum strongly resembles that observed for $\left[\mathrm{Eu} . \mathrm{L}^{1}\right]$ and related $\mathrm{C}_{3}$ symmetric aralkynyl complexes in solution, as expected. ${ }^{12,13}$ The interaction between the chromophores evident in the packing diagram may help to explain the low overall emission quantum yield of $0.2 \%$, as the intermolecular $\pi$-stacking may enhance charge transfer quenching of the intermediate triazole excited states.
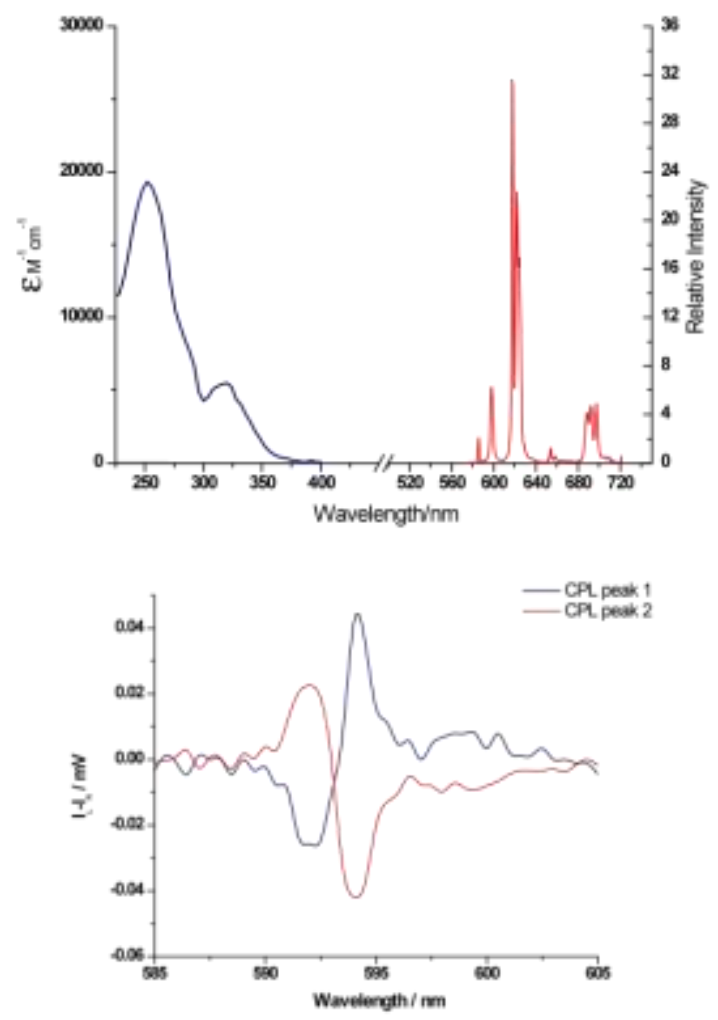

Figure $5 \quad$ upper: Absorption and emission spectra of [Eu. $\left.\mathrm{L}^{2}\right],(\mathrm{MeOH}, 295 \mathrm{~K})$; lower: $\mathrm{CPL}$ spectrum of the $\Delta J=1$ region showing near mirror image spectra of the $\Delta$ (blue: eluting first) and $\Lambda$ (red) enantiomers (n.b. photobleaching occurred during data acquisition, leading to a loss of sensitivity: 10 scans were recorded (1 min each) and summed; [complex] = $110 \mu \mathrm{mol})$.

\footnotetext{
${ }^{2}$ This complex was insoluble in pure water; hence, solution characterisation was carried out in methanol.
} 
The complex [Eu.L ${ }^{2}$ ] was analysed by chiral HPLC. The $\Delta$ and $\Lambda$ enantiomers were separated using a ChiralPAK ID column, with isocratic $\mathrm{MeOH}$ as eluent. The separated isomers were examined by CPL $\left(\lambda_{\text {exc }} 320 \mathrm{~nm}\right)$ and near mirror image spectra were observed. This particular complex (vide infra) is 1000 times less bright than the alkynyl analogues discussed below, and was also rather sensitive to photobleaching during CPL data acquisition, for which ten consecutive scans were recorded and averaged. The sign and sequence of the CPL transitions observed were almost identical to those of $\left[\mathrm{Eu} . \mathrm{L}^{1}\right]$ and its derivatives and analogues. ${ }^{23,24}$ The absolute configuration of the enantiomeric complex that eluted first was therefore deduced to be $\Delta$ and, by analogy, it must have an $S S S$ configuration at each chiral $\mathrm{P}$ centre and a $\lambda$ configuration in each of the three $\mathrm{NCH}_{2} \mathrm{CH}_{2} \mathrm{~N}$ chelate rings. Considering that related chiral $\operatorname{Ln}(\mathrm{III})$ complexes have been shown to give rise to large circularly polarised luminescence $(\mathrm{CPL})^{24}$ and that CPL spectroscopy and, in particular, microscopy remain under-exploited, ${ }^{25}$ the ability to separate these enantiomers easily when substituted with large groups at the 4-pyridyl position is likely to be rather useful in the development of chiral probes for future chiroptical studies.

\section{Sonogashira coupling reactions of tris(4-bromopyridyl) complexes}

The carbon-bromine bond in 4-substituted pyridine derivatives is activated towards oxidative addition by low-valent Pd species. Indeed, the ligation of the pyridine lone pair to the europium(III) centre in $\left[\mathrm{Eu} . \mathrm{L}^{1}\right]$ may enhance this reactivity, as the europium can act as a charge sink stabilising any build up of charge in the heterocyclic ring. ${ }^{26}$ Using a mixture of THF and DMF, it was possible to solubilise the active palladium-bisphospinoferrocenyl catalyst and the europium complex sufficiently to allow the alkyne coupling reaction to occur at $65^{\circ} \mathrm{C}$ (Scheme 2). Using [Eu.L $\left.{ }^{1}\right]$ as the precursor, three different alkynes were coupled, to give the complexes, [Eu.L $\mathrm{L}^{3-5}$ ], in $30-48 \%$ yield. Analysis of each Sonogashira reaction by LC-MS revealed quantitative conversion of $\left[\mathrm{Eu} . \mathrm{L}^{1}\right]$ to the desired tris-alkynyl product. However, loss of material in purification of each complex by reverse-phase HPLC contributed significantly to the moderate yields obtained. 


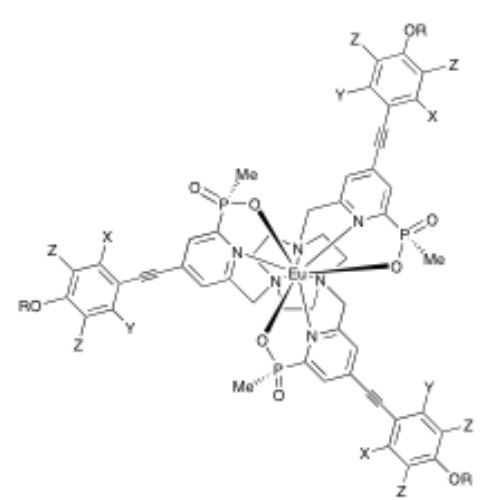

[Eu. $\mathrm{L}^{3}$ ] $X=\mathrm{Y}=\mathrm{H} ; \mathrm{Z}=\mathrm{OMe}, \mathrm{R}=\mathrm{Me}$

[Eu.L'] $\mathrm{X}=\mathrm{Y}=\mathrm{OMe} ; \mathrm{Z}=\mathrm{H} ; \mathrm{R}=\mathrm{CH}_{2} \mathrm{CO}_{2}{ }^{\mathrm{t}} \mathrm{Bu}$

[Eu.L. $L^{5}$ ] $\mathrm{X}=\mathrm{Z}=\mathrm{H} ; \mathrm{R}=\mathrm{CH}_{2} \mathrm{CO}_{2} \mathrm{Me}$

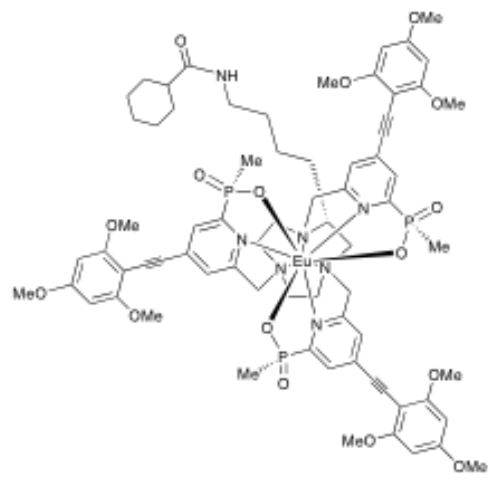

$S-\Lambda-R R R-\delta \delta \delta \cdot\left[\mathrm{Eu} . L^{6}\right]$

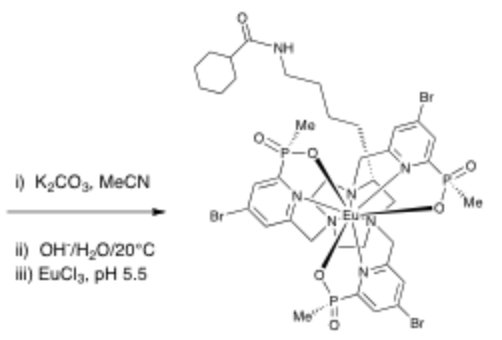

[Eu.L ${ }^{16}$ ]

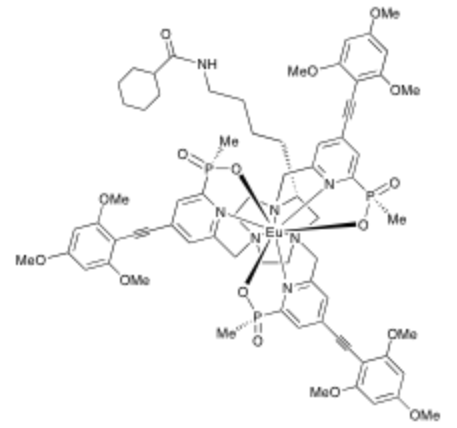

S-A-RRR- $\delta \delta \delta-\left[\right.$ Eu. L $\left.{ }^{6}\right]$

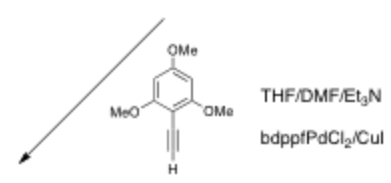

Scheme $2 \quad$ Synthesis of the enantiopure complex $\left[E u . L^{6}\right]$

Table 1 Selected photophysical data for Eu complexes (MeOH, $295 \mathrm{~K}$ )

\begin{tabular}{lcccc}
\hline Complex & $\lambda_{\max } \mathrm{nm}$ & $\varepsilon \mathrm{mM}^{-1} \mathrm{~cm}^{-1}$ & $\phi_{\mathrm{em}} \%$ & $\tau_{\mathrm{Eu}} \mathrm{ms}$ \\
\hline$\left[\right.$ Eu.L $\left.{ }^{2}\right]$ & 320 & 5.50 & 0.2 & 1.33 \\
{$\left[\right.$ Eu.L $\left.{ }^{3}\right]$} & 332 & 56.4 & 47 & 1.15 \\
{$\left[\right.$ Eu.L $\left.{ }^{4}\right]$} & 355 & 55.0 & 43 & 1.13 \\
{$\left[\right.$ Eu.L $\left.{ }^{5}\right]$} & 331 & 56.6 & 44 & 1.10 \\
{$\left[\right.$ Eu.L $\left.\mathrm{L}^{6}\right]$} & 355 & 55.1 & 55 & 1.05 \\
\hline
\end{tabular}


Using the analogous C-substituted complex, $\left[\mathrm{Eu} . \mathrm{L}^{1 \mathrm{~b}}\right]$, derived from $S$-lysine and $76 \%$

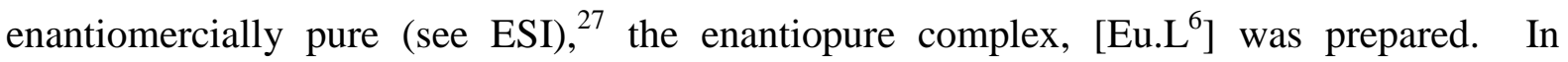
methanol solution, each of these Eu complexes is particularly bright, with molar extinction coefficients of the order of $55 \mathrm{mM}^{-1} \mathrm{~cm}^{-1}$ and overall emission quantum yields of 44 to $55 \%$ (Table 1 and Figure 6). Such properties greatly accelerate the acquisition of CPL data, and the CPL spectrum of [Eu. $\left.{ }^{6}\right]$ showed strong transitions in the $\Delta J=1(589-600 \mathrm{~nm})$ and $\Delta J=4$ manifold (680 to $715 \mathrm{~nm}$ ) in particular. The sequence and sign of the observed transitions were consistent ${ }^{23-25}$ with formation of a $\Lambda$ overall complex helicity, so that the complete stereochemical description of this complex is $S-\Lambda-R R R-\delta \delta \delta$-[Eu.L $\left.{ }^{6}\right]$. Given that the brightness, $B$, of this complex in methanol is about 25 to $30 \mathrm{mM}^{-1} \mathrm{~cm}^{-1}$ and that the observed $g_{\text {em }}$ values are in the range 0.1 to 0.3 (Figure 6), this complex gives the strongest CPL signal yet observed for any lanthanide complex in solution, ${ }^{25}$ allowing the spectrum to be acquired with good signal intensity over a period of 20 minutes, using a $3 \mu \mathrm{M}$ solution of the complex.
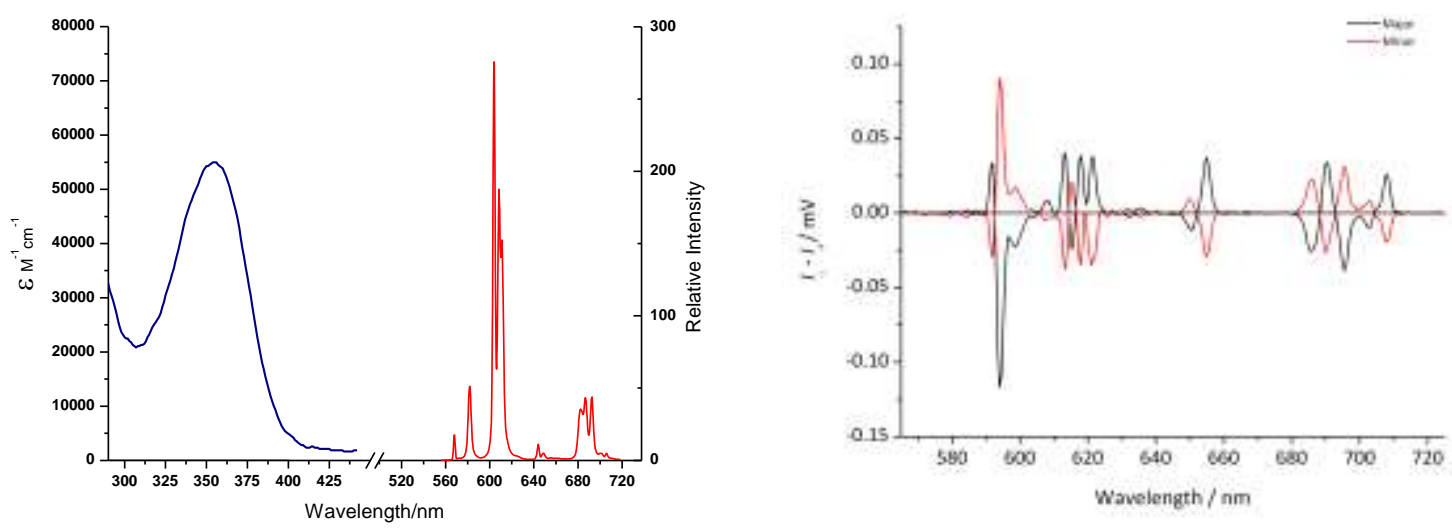

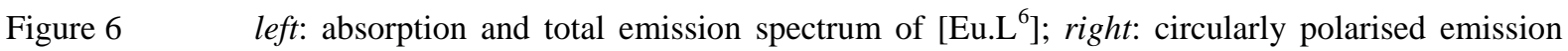
spectra of (major/black) S-RRR- $\Lambda$-[Eu.L $\left.{ }^{6}\right],\left(\mathrm{MeOH}, 295 \mathrm{~K}, 3 \mu \mathrm{M}, 20 \mathrm{~min} ; g_{\mathrm{em}}=+0.30(708 \mathrm{~nm}) ;+0.17(655\right.$ $\mathrm{nm}) ;-0.11(598 \mathrm{~nm})$ ), and the enantiomeric $\Delta$-complex (red/minor) with an $R$ stereogenic centre at $\mathrm{C}$.

\section{Summary and Conclusions}

A tris-pyridyl-triazole-aryl Eu(III) complex and a set of four strongly emissive aralkynyl analogues can be synthesised from a common tris(4-bromopyridine) intermediate in one-pot reaction sequences. Given that, in the past, most sensitising groups in europium complexes have been integrated at an earlier stage in the synthetic route, the approach illustrated here offers much greater scope for the creation of larger families of complexes, as the route is inherently divergent. For example, it can be anticipated that a wide range of functionality 
may be incorporated into the aryl ring in each example, allowing interaction with targets of interest. Considering that the racemic complexes may be readily resolved by chiral HPLC, the generation of a series of enantiopure complexes for CPL investigations may also be envisaged.

\section{Acknowledgements}

We thank the ERC (FCC 266804), CISbio Bioassays, the Royal Society and EPSRC for support, and the Diamond Light Source for an award of instrument time at the station I19 (MT 8682) and the instrument scientists for their kind support.

\section{Experimental}

X-Ray Crystallography. The data for compound [Eu. $\mathrm{L}^{2}$ ] were collected at $100.0 \mathrm{~K}$ on a Rigaku Saturn 724+ diffractometer at station I19 of the Diamond Light Source synchrotron (undulator, $\lambda=0.6889 \AA$, $\omega$-scan, 1.0\%/frame, Cryostream (Oxford Cryosystems) nitrogen open-flow cryostat) and processed using Bruker APEXII software. The structure was solved by direct method and refined by full-matrix least squares on $\mathrm{F}^{2}$ for all data using SHELXTL ${ }^{29}$ and OLEX $2^{30}$ software. All non-disordered non-hydrogen atoms were refined anisotropically, the hydrogen atoms were placed in the calculated positions and refined in riding mode. Disordered atoms were refined isotropically with fixed $\mathrm{SOF}=0.5$. The channels in the structure of $\left[\mathrm{Eu} \cdot \mathrm{L}^{2}\right]$ contain a number of severely disordered solvent molecules (139e/independent part of the unit cell) that were taken into account by applying a MASK procedure in the OLEX2 program package. Crystallographic data for the structure have been deposited with the Cambridge Crystallographic Data Centre as supplementary publication CCDC-982687.

Crystal Data for [Eu.L ${ }^{2}$ ]: $\mathrm{C}_{54} \mathrm{H}_{61} \mathrm{EuN}_{15} \mathrm{O}_{11} \mathrm{P}_{3}(M=1341.05)$ : monoclinic, space group $\mathrm{C} 2 / \mathrm{c}$ (no. 15), $a=59.156(4), b=13.3370(10), c=18.5660(10) \AA, \beta=102.310(3)^{\circ}, V=$ 14311.1(16) $\AA^{3}, Z=8, T=100.0(1) \mathrm{K}, \mu($ Synchrotron $)=0.926 \mathrm{~mm}^{-1}$, Dcalc $=1.245 \mathrm{~g} / \mathrm{mm}^{3}$, 56723 reflections measured $(1.36 \leq 2 \Theta \leq 48.58)$, 11499 unique reflections $\left(R_{\text {int }}=0.0892\right)$ were used in all calculations. The final $R_{1}$ was $0.0510(7477>2 \sigma(\mathrm{I}))$ and $w R_{2}$ was 0.1309 (all data), GOF $=0.989$. 


\section{NMR spectroscopy and mass spectrometry}

${ }^{1} \mathrm{H},{ }^{13} \mathrm{C},{ }^{19} \mathrm{~F}$ and ${ }^{31} \mathrm{P}$ NMR spectra were recorded in commercially-available deuteriated solvents on a Varian Mercury-200 $\left({ }^{1} \mathrm{H}\right.$ at $199.97 \mathrm{MHz},{ }^{13} \mathrm{C}$ at $\left.50.29 \mathrm{MHz}\right)$, Varian Mercury-400 or Bruker Avance$400\left({ }^{1} \mathrm{H}\right.$ at $399.96 \mathrm{MHz},{ }^{13} \mathrm{C}$ at $100.57 \mathrm{MHz},{ }^{31} \mathrm{P}$ at $\left.161.94 \mathrm{MHz}\right)$, Varian Inova-500 $\left({ }^{1} \mathrm{H}\right.$ at 499.77 $\mathrm{MHz},{ }^{13} \mathrm{C}$ at $125.67 \mathrm{MHz}$,) or Varian VNMRS-700 $\left({ }^{1} \mathrm{H}\right.$ at $699.73 \mathrm{MHz},{ }^{31} \mathrm{P}$ at $\left.283.26 \mathrm{MHz}\right)$ spectrometer. Electrospray mass spectra were recorded on a Waters Micromass LCT or ThermoFinnigan LTQ FT instrument operating in positive or negative ion mode as stated, with methanol as the carrier solvent. Accurate mass spectra were recorded using the Thermo-Finnigan LTQ FT mass spectrometer.

\section{Alkyne synthesis: 3,4,5-Trimethoxyphenylacetylene}

1,1-Dibromo-2-(3,4,5-trimethoxyphenyl)-ethylene (1.41 g, $4.04 \mathrm{mmol})$ was dissolved in anhydrous THF $(30 \mathrm{~mL})$ and cooled to $-78^{\circ} \mathrm{C}$. $n$-Butyl lithium $(2.5 \mathrm{M}$ in hexane, $6.4 \mathrm{~mL}, 16.2 \mathrm{mmol})$ was added slowly and the mixture was stirred at $-78{ }^{\circ} \mathrm{C}$ under argon for $30 \mathrm{~min}$. Water $(8 \mathrm{~mL})$ was added and the mixture was extracted with EtOAc $(2 \times 30 \mathrm{~mL})$. The combined organic fractions were washed with half-strength brine solution $(30 \mathrm{~mL})$, dried $\left(\mathrm{MgSO}_{4}\right)$, and the solvent was removed under reduced pressure. The residue thus obtained was subjected to column chromatography (silica gel; neat hexane, then hexane/EtOAc, 9:1 v/v) to give 3,4,5-trimethoxyphenylacetylene as a white solid $(0.53 \mathrm{~g}, 68 \%)$; m.p. 71-73 ${ }^{\circ} \mathrm{C}$ (lit. ${ }^{1}$ m.p. $\left.70-71{ }^{\circ} \mathrm{C}\right) ;{ }^{1} \mathrm{H}$ NMR $\left(400 \mathrm{MHz}, \mathrm{CDCl}_{3}\right) \delta 6.72\left(2 \mathrm{H}, \mathrm{s}, \mathrm{H}^{4}\right), 3.85\left(3 \mathrm{H}, \mathrm{s}, \mathrm{H}^{8}\right)$, $3.84\left(6 \mathrm{H}, \mathrm{s}, \mathrm{H}^{7}\right), 3.03\left(1 \mathrm{H}, \mathrm{s}, \mathrm{H}^{1}\right) ;{ }^{13} \mathrm{C}$ NMR $\left(151 \mathrm{MHz}, \mathrm{CDCl}_{3}\right) \delta 153.1\left(\mathrm{C}^{5}\right), 139.3\left(\mathrm{C}^{6}\right), 117.0\left(\mathrm{C}^{3}\right)$, $109.4\left(\mathrm{C}^{4}\right), 83.7\left(\mathrm{C}^{2}\right), 76.2\left(\mathrm{C}^{1}\right), 61.0\left(\mathrm{C}^{8}\right), 56.2\left(\mathrm{C}^{7}\right)$; (HRMS+) $\mathrm{m} / \mathrm{z} 193.0845[\mathrm{M}+\mathrm{H}]^{+}\left(\mathrm{C}_{11} \mathrm{H}_{13} \mathrm{O}_{3}\right.$ requires 193.0865); $R_{f}=0.45$ (silica; hexane/EtOAc $4: 1 \mathrm{v} / \mathrm{v}$ ). The spectral data were consistent with those reported previously. ${ }^{28}$

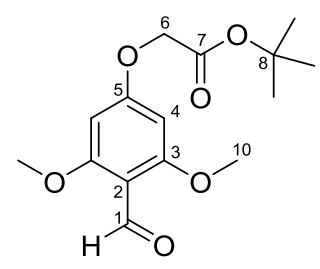

\section{tert-Butyl (4-formyl-3,5-dimethoxyphenoxy)acetate}

To a solution of 4-hydroxy-2,6-dimethoxybenzaldehyde $(1.00 \mathrm{~g}, 5.49 \mathrm{mmol})$ in a dichloromethane/dimethylformamide mixture $(5: 1,36 \mathrm{~mL})$ under argon was added potassium carbonate $(1.52 \mathrm{~g}, 11.0 \mathrm{mmol})$ and tert-butyl bromoacetate $(1.62 \mathrm{~mL}, 2.14 \mathrm{~g}, 11.0 \mathrm{mmol})$. The mixture was stirred for $24 \mathrm{~h}$ at which point the potassium carbonate was removed by gravity filtration. The dichloromethane was removed under reduced pressure and the dimethylformamide was removed by vacuum distillation to give the product as a white solid (1.35 g, 83\%), which was used without 
further purification; m.p. $130-132{ }^{\circ} \mathrm{C} ;{ }^{1} \mathrm{H}$ NMR $\left(400 \mathrm{MHz}, \mathrm{CDCl}_{3}\right) \delta 1.50\left(9 \mathrm{H}, \mathrm{s}, \mathrm{H}^{9}\right), 3.86(6 \mathrm{H}, \mathrm{s}$, $\left.\mathrm{H}^{10}\right), 4.57\left(2 \mathrm{H}, \mathrm{s}, \mathrm{H}^{6}\right), 6.08\left(2 \mathrm{H}, \mathrm{s}, \mathrm{H}^{4}\right), 10.35\left(1 \mathrm{H}, \mathrm{s}, \mathrm{H}^{1}\right) ;{ }^{13} \mathrm{C} \mathrm{NMR}\left(101 \mathrm{MHz}, \mathrm{CDCl}_{3}\right) \delta 28.2,56.2$, 65.7, 83.2, 91.0, 109.5 164.2, 164.4, 167.2, 187.9; LRMS (ESI) m/z $297[\mathrm{M}+\mathrm{H}]^{+}$; $\left(\mathrm{HRMS}^{+}\right) \mathrm{m} / \mathrm{z}$ $297.1331[\mathrm{M}+\mathrm{H}]^{+}\left(\mathrm{C}_{15} \mathrm{H}_{21} \mathrm{O}_{6}\right)$ requires 297.1338.

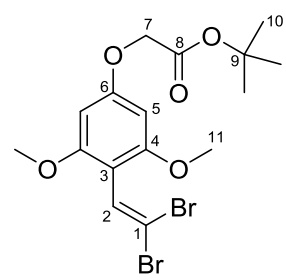

\section{tert-Butyl [4-(2,2-dibromoethenyl)-3,5-dimethoxyphenoxy]acetate}

To a solution of triphenylphosphine $(4.62 \mathrm{~g}, 17.6 \mathrm{mmol})$ and tetrabromomethane $(2.92 \mathrm{~g}, 8.8 \mathrm{mmol})$ in anhydrous dichloromethane $(15 \mathrm{~mL})$ under argon at $0{ }^{\circ} \mathrm{C}$ was added a solution of tert-butyl (4formyl-3,5-dimethoxyphenoxy)acetate $(1.30 \mathrm{~g}, 4.4 \mathrm{mmol})$ in anhydrous dichloromethane $(15 \mathrm{~mL})$. The resulting red solution was stirred for 18 hours. The solvent was removed under reduced pressure and the residue was stirred in diethyl ether, filtered and concentrated under reduced pressure. The crude product was purified by column chromatography (silica, neat hexane to $5: 1 \mathrm{v} / \mathrm{v}$ hexane/ethyl acetate) to give the product as a white solid $(1.22 \mathrm{~g}, 62 \%)$; m.p. $122-124{ }^{\circ} \mathrm{C} ;{ }^{1} \mathrm{H} \mathrm{NMR}(400 \mathrm{MHz}$, $\left.\mathrm{CDCl}_{3}\right) \delta 1.50\left(9 \mathrm{H}, \mathrm{s}, \mathrm{H}^{10}\right), 3.79\left(6 \mathrm{H}, \mathrm{s}, \mathrm{H}^{11}\right), 4.52\left(2 \mathrm{H}, \mathrm{s}, \mathrm{H}^{7}\right), 6.11\left(2 \mathrm{H}, \mathrm{s}, \mathrm{H}^{5}\right), 7.17\left(1 \mathrm{H}, \mathrm{s}, \mathrm{H}^{2}\right)$; ${ }^{13} \mathrm{C}$ NMR $\left(101 \mathrm{MHz}, \mathrm{CDCl}_{3}\right) \delta 28.2,55.8,65.9,82.7,91.3,93.1,107.8,130.9,158.1,160.1,167.9$; LRMS (ESI) $m / z, 451 ;\left(\mathrm{HRMS}^{+}\right) \mathrm{m} / z, 450.9771[\mathrm{M}+\mathrm{H}]^{+}\left(\mathrm{C}_{16} \mathrm{H}_{21} \mathrm{O}_{6}{ }^{79} \mathrm{Br}_{2}\right)$ requires 450.9756.

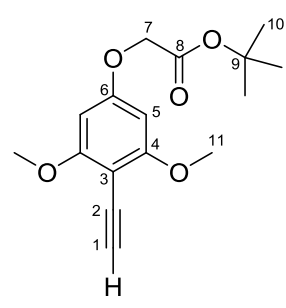

\section{tert-Butyl (4-ethynyl-3,5-dimethoxyphenoxy)acetate}

To a solution of tert-Butyl [4-(2,2-dibromoethenyl)-3,5-dimethoxyphenoxy]acetate (0.797 g, 1.77 $\mathrm{mmol})$ in dry THF $(20 \mathrm{~mL})$ under argon at $-78^{\circ} \mathrm{C}$, was added n-butyllithium $(1.42 \mathrm{~mL}$ of a $2.5 \mathrm{M}$ solution, $3.54 \mathrm{mmol}$ ). The solution was stirred for $30 \mathrm{~min}$ when a further 0.5 eq. of n-butyllithium was added. The mixture was stirred for a further $15 \mathrm{~min}$ before water $(20 \mathrm{~mL})$ was added. THF was removed under reduced pressure and the remaining aqueous solution was extracted into dichloromethane $(3 \times 30 \mathrm{~mL})$. The organic layers were combined, dried over $\mathrm{MgSO}_{4}$, filtered and concentrated under reduced pressure. The crude product was purified by column chromatography (silica, hexane/ethyl acetate $8: 1 \mathrm{v} / \mathrm{v}$ ) to give the product as a white solid (0.248 g, 48\%); m.p. 107-108 
${ }^{\circ} \mathrm{C} ;{ }^{1} \mathrm{H}$ NMR $\left(700 \mathrm{MHz}, \mathrm{CDCl}_{3}\right) \delta 1.49\left(9 \mathrm{H}, \mathrm{s}, \mathrm{H}^{10}\right), 3.49\left(1 \mathrm{H}, \mathrm{s}, \mathrm{H}^{1}\right), 3.86\left(6 \mathrm{H}, \mathrm{s}, \mathrm{H}^{11}\right), 4.53(2 \mathrm{H}, \mathrm{s}$, $\left.\mathrm{H}^{7}\right), 6.11\left(2 \mathrm{H}, \mathrm{s}, \mathrm{H}_{5}\right) ;{ }^{13} \mathrm{C} \mathrm{NMR}\left(176 \mathrm{MHz}, \mathrm{CDCl}_{3}\right) \delta 28.2\left(\mathrm{C}^{9}\right), 56.3\left(\mathrm{C}^{11}\right), 65.9\left(\mathrm{C}^{7}\right), 76.4\left(\mathrm{C}^{2}\right), 82.9$ $\left(C^{9}\right), 84.2\left(C^{1}\right), 91.2\left(C^{5}\right), 94.1\left(C^{3}\right), 160.2\left(C^{6}\right), 163.1\left(C^{4}\right), 167.6\left(C^{8}\right)$; LRMS (ESI) $\mathrm{m} / \mathrm{z} 293[\mathrm{M}+$ $\mathrm{H}]^{+} ;\left(\mathrm{HRMS}^{+}\right) \mathrm{m} / z 293.1390[\mathrm{M}+\mathrm{H}]^{+}\left(\mathrm{C}_{16} \mathrm{H}_{21} \mathrm{O}_{6}\right)$ requires 293.1389.

\section{Ligand and Complex synthesis}

\section{[Eu. $\left.\mathbf{L}^{1}\right]$}

The synthesis of the tris $p$-bromo Eu(III) complex [Eu.. ${ }^{\mathbf{1}}$ ] has been reported elsewhere. ${ }^{23}{ }^{1} \mathrm{H}$ NMR $\left(400 \mathrm{MHz}, \mathrm{CD}_{3} \mathrm{OD}\right) \delta 8.60(1 \mathrm{H}, \mathrm{s}, \mathrm{py} H), 7.97(1 \mathrm{H}, \mathrm{s}, \mathrm{pyC} H \mathrm{~N}), 7.12(1 \mathrm{H}, \mathrm{s}, \mathrm{py} H), 4.36(1 \mathrm{H}, \mathrm{s}$, $\left.\mathrm{NCH}^{\prime}{ }_{\text {eq }}\right), 0.54\left(3 \mathrm{H}, \mathrm{s}, \mathrm{CH}_{3}\right),-0.77\left(1 \mathrm{H}, \mathrm{s}, \mathrm{pyCH} H^{\prime} \mathrm{N}\right),-1.37\left(1 \mathrm{H}, \mathrm{s}, \mathrm{NCH}{ }^{\prime}{ }_{\mathrm{ax}}\right),-2.23\left(1 \mathrm{H}, \mathrm{s}, \mathrm{NCH}_{\text {eq }}\right),-5.28$ $\left(1 \mathrm{H}, \quad \mathrm{s}, \quad \mathrm{NCH} H_{\mathrm{ax}}\right) .{ }^{31} \mathrm{P} \mathrm{NMR}\left(162 \mathrm{MHz}, \mathrm{CD}_{3} \mathrm{OD}\right)+39.8 . \quad \mathrm{m} / \mathrm{z}\left(\mathrm{HRMS}^{+}\right) 1020.851[\mathrm{M}+\mathrm{H}]^{+}$ $\left(\mathrm{C}_{27} \mathrm{H}_{34}{ }^{79} \mathrm{Br}_{3} \mathrm{~N}_{6} \mathrm{O}_{6} \mathrm{P}_{3}{ }^{151} \mathrm{Eu}\right.$ requires 1020.849). $\mathrm{R}_{f}=0.31$ (silica; $\mathrm{CH}_{2} \mathrm{Cl}_{2} / \mathrm{CH}_{3} \mathrm{OH} /$ aq. ammonia: $82 / 15 / 3: \mathrm{v} / \mathrm{v} / \mathrm{v})$

\section{[Eu. $\left.\mathbf{L}^{2}\right]$}

CAUTION! Care should be taken using azides and (poly)triazoles, particularly if scaling up the reaction conditions stated here.

To a solution of [Eu.L $\left.{ }^{1}\right](5.0 \mathrm{mg}, 4.9 \mu \mathrm{mol})$ in DMF $(0.5 \mathrm{~mL}), \mathrm{NaN}_{3}(3.8 \mathrm{mg}, 59 \mu \mathrm{mol})$ was added. The reaction was heated to $70^{\circ} \mathrm{C}$, and monitored by LC-MS until full substitution of the three bromines was complete (within $16 \mathrm{~h}$ ). The reaction was cooled to RT, and 4-ethynylanisole ( $2.9 \mathrm{mg}$, $22 \mu \mathrm{mol})$, TBTA $(1.6 \mathrm{mg}, 2.9 \mu \mathrm{mol}), \mathrm{CuSO}_{4} .5 \mathrm{H}_{2} \mathrm{O}(0.7 \mathrm{mg}, 2.9 \mu \mathrm{mol})$ in $^{\mathrm{H}_{2} \mathrm{O}}(0.5 \mathrm{~mL})$ and sodium ascorbate $(1.2 \mathrm{mg}, 5.9 \mu \mathrm{mol})$ were added, and the progress of the reaction monitored by LC-MS. Full conversion was observed within $1 \mathrm{~h}$, with the solution darkening from very pale yellow to pale green over this time. The reaction mixture was evaporated onto silica, and the material purified by silica gel chromatography (silica, $\mathrm{CH}_{2} \mathrm{Cl}_{2}: \mathrm{CH}_{3} \mathrm{OH} 95: 5$ to $80: 20 ; \mathrm{R}_{f}=0.15, \mathrm{CH}_{2} \mathrm{Cl}_{2}: \mathrm{CH}_{3} \mathrm{OH} 90: 10$ ), then reverse phase HPLC (XBridge $\mathrm{C} 1810 \mathrm{~cm} 3.5 \mu \mathrm{m}, \mathrm{H}_{2} \mathrm{O} / \mathrm{CH}_{3} \mathrm{OH}$ with $0.1 \% \mathrm{HCOOH}$ gradient elution), to give the tris-triazole complex as a white solid (1.0 mg, isolated yield $16 \%$ ).

$\delta_{\mathrm{H}}\left(400 \mathrm{MHz}, \mathrm{CD}_{3} \mathrm{OD}\right)$ 9.34, 8.94, 7.96, 7.47, $7.11(\mathrm{~s}+\mathrm{s}+\mathrm{s}+\mathrm{s}+\mathrm{s}+\mathrm{s}, \mathrm{ArCH}$ and triazole $\mathrm{CH}) 7.90$ $\left(3 \mathrm{H}\right.$, br s pyCH); $4.55\left(3 \mathrm{H}\right.$, br s, $\left.\mathrm{CH}_{\mathrm{eq}}\right) ; 3.89(9 \mathrm{H} \mathrm{s}, \mathrm{OMe}) ; 0.84(9 \mathrm{H}$, br s, PMe); -0.51 (3H br s, $\left.\mathrm{CH}_{\mathrm{py}}\right)$; $-1.11\left(3 \mathrm{H}\right.$, br s $\left.\mathrm{H}_{\mathrm{ax}}\right) ;-1.71\left(3 \mathrm{H}\right.$, br s $\left.\mathrm{H}_{\mathrm{eq}}\right) ;-4.95\left(3 \mathrm{H}\right.$, br s, $\left.\mathrm{H}_{\mathrm{ax}}\right) . \quad \delta_{\mathrm{P}}\left(162 \mathrm{MHz}, \mathrm{CD}_{3} \mathrm{OD}\right)$ +39.2. $m / z\left(\right.$ HRMS $\left.^{+}\right) 1304.296[\mathrm{M}+\mathrm{H}]^{+}\left(\mathrm{C}_{54} \mathrm{H}_{58} \mathrm{~N}_{15} \mathrm{O}_{9} \mathrm{P}_{3}{ }^{151}\right.$ Eu requires 1304.297).

$\lambda_{\max }(\mathrm{MeOH})=320 \mathrm{~nm}\left(5500 \mathrm{M}^{-1} \mathrm{~cm}^{-1}\right) ; \tau_{\mathrm{Ev}}\left(\mathrm{CH}_{3} \mathrm{OH}\right) 1.33 \mathrm{~ms} ; \phi_{\mathrm{em}}(\mathrm{MeOH}) 0.2 \%$. 
RP- HPLC: $t_{\mathrm{R}}=9.7 \mathrm{~min}$ (XBridge $\mathrm{C} 1810 \mathrm{~cm} 3.5 \mu \mathrm{m}, \mathrm{H}_{2} \mathrm{O} / \mathrm{CH}_{3} \mathrm{OH}$ with $0.1 \% \mathrm{HCOOH}$ [gradient elution, see Table below for details], $1 \mathrm{~mL} / \mathrm{min}, \lambda=320 \mathrm{~nm}, 293 \mathrm{~K}$ ).

Details of the reverse phase HPLC eluant gradient:

\begin{tabular}{llll} 
Time / min & $\mathrm{H}_{2} \mathrm{O}(+0.1 \% \mathrm{HCOOH})$ & $\mathrm{MeOH}(+0.1 \% \mathrm{HCOOH})$ & Curve \\
\hline 2.0 & 60 & 40 & 0 \\
10.0 & 5 & 95 & 1 \\
2.0 & 5 & 95 & 0 \\
0.5 & 90 & 10 & 1 \\
2.0 & 90 & 10 & 0
\end{tabular}

Chiral HPLC: $t_{\mathrm{R}}=22.7 \mathrm{~min}$ and $61.4 \mathrm{~min}$ (CHIRALPAK-ID, $4.0 \mathrm{~mm} \times 250 \mathrm{~mm}, \mathrm{CH}_{3} \mathrm{OH}, 1 \mathrm{~mL} / \mathrm{min}$, $295 \mathrm{~K}$ ). On the semi-preparative column at $2.5 \mathrm{~mL} / \mathrm{min}$, the complexes eluted after 87 and 226 minutes. By analysis of the CPL emission signature with related complexes of established helicity, the first eluted complex was assigned the $\boldsymbol{\Delta}$ absolute configuration. ${ }^{23,24,25}$

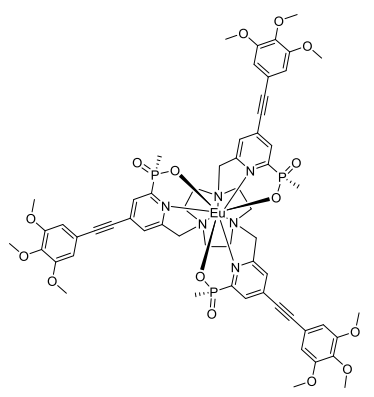

\section{[Eu.L $\left.\mathbf{L}^{3}\right]$}

To a stirred, degassed solution of the tris $p$-bromo Eu(III) complex [Eu. $\mathbf{L}^{\mathbf{1}}$ ] $(5 \mathrm{mg}, 4.9 \mu \mathrm{mol})$ in a mixture of anhydrous THF/DMF (2:3 v/v, $500 \mu \mathrm{L})$ was added 3,4,5-trimethoxyphenylacetylene (3.1 $\mathrm{mg}, 16.1 \mu \mathrm{mol})$ and triethylamine $(14 \mu \mathrm{L}, 98 \mu \mathrm{mol}$ ), and the solution was degassed (freeze-thaw cycle) three times. [1,1-Bis(diphenylphosphino)ferrocene]dichloropalladium(II) $(1.2 \mathrm{mg}, 1.47 \mu \mathrm{mol})$ and $\mathrm{CuI}(0.3 \mathrm{mg}, 1.5 \mu \mathrm{mol})$ were added and the resulting yellow solution was stirred at $65{ }^{\circ} \mathrm{C}$ under argon for $12 \mathrm{~h}$. After this time the solution turned dark brown and LC-MS analysis revealed complete conversion of starting material. The solvent was removed under reduced pressure and the brown residue was purified by semi-preparative RP-HPLC [gradient: $50-100 \%$ methanol in water $(0.1 \%$ formic acid) over $10 \mathrm{~min} ; \mathrm{t}_{R}=9.8 \mathrm{~min}$ ] to give a white solid (2.6 $\left.\mathrm{mg}, 40 \%\right)$; LRMS (ESI) $\mathrm{m} / z 1355$ $[\mathrm{M}+\mathrm{H}]^{+}, 678[\mathrm{M}+2 \mathrm{H}]^{2+} ;\left(\mathrm{HRMS}^{+}\right) \mathrm{m} / z 1355.305\left[\mathrm{M}\left({ }^{151} \mathrm{Eu}\right)+\mathrm{H}\right]^{+}\left(\mathrm{C}_{60} \mathrm{H}_{67} \mathrm{~N}_{6} \mathrm{O}_{15} \mathrm{P}_{3}{ }^{151}\right.$ Eu requires $1355.308) ; \tau_{M e O H}=1.15 \mathrm{~ms}$ and $0.91 \mathrm{~ms}\left(\mathrm{H}_{2} \mathrm{O}\right) ; \Phi_{M e O H}^{e m}=47( \pm 15) \% ; \varepsilon_{\mathrm{MeOH}}(332 \mathrm{~nm})=56,400 \mathrm{M}^{-}$ ${ }^{1} \mathrm{~cm}^{-1} \cdot t_{\mathrm{R}}=9.8 \min (50$ to $100 \% \mathrm{MeOH}$ in water $+0.1 \%$ formic acid $)$. 
Triethyl 6,6',6"-((S)-2-(4-(cyclohexanecarboxamido)butyl)-1,4,7-triazacyclononane1,4,7-triyl)tris(methylene)tris(4-bromopyridine-6,2-diyl)tris(methylphosphinate), $\mathrm{L}^{1 \mathrm{~b}}$

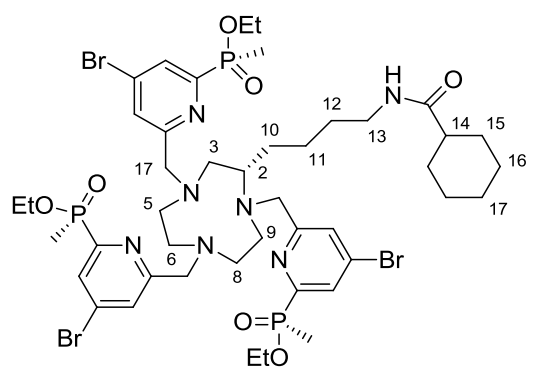

(S)-N-(4-(1,4,7-Triazacyclononan-2-yl)butyl)cyclohexanecarboxamide ${ }^{27} \quad(75 \quad \mathrm{mg}, \quad 0.24$ mmol), was added to a solution of (4-bromo-6-(ethoxy(methyl)phosphoryl)pyridin-2yl)methyl methanesulfonate $(320 \mathrm{mg}, 0.86 \mathrm{mmol})$ and $\mathrm{K}_{2} \mathrm{CO}_{3}(198 \mathrm{mg}, 1.47 \mathrm{mmol})$ in dry $\mathrm{CH}_{3} \mathrm{CN}(15 \mathrm{~mL})$ and stirred under argon at $65^{\circ} \mathrm{C}$. After $6 \mathrm{~h}$ the solution was allowed to cool to RT and filtered. The filtrate was concentrated and purified by HPLC (Method $A, \mathrm{t}_{\mathrm{R}}=8.5$ $\mathrm{min})$ to give a yellow oil as a mixture of diastereoisomers, $(65 \mathrm{mg}, 25 \%)$; $\delta_{\mathrm{H}}\left(\mathrm{CDCl}_{3}\right) 8.20$ 7.82 (6H, m, py), 6.45 (1H, br, CONH), 4.17-3.87 (12H, m, $\mathrm{POCH}_{2}$ and $\mathrm{H}^{\left.17-17^{\prime}-17^{\prime \prime}\right)}$ ), 3.23-2.59 $\left(13 \mathrm{H}, \mathrm{m}, \mathrm{H}^{2-3-5-6-8-9-13}\right), 1.82-1.76\left(9 \mathrm{H}, \mathrm{m}, \mathrm{PCH}_{3}\right), 1.76-1.26\left(26 \mathrm{H}, \mathrm{m}, \mathrm{CH}_{3}(\mathrm{Et})\right.$ and $\mathrm{H}^{10-11-12-14-}$ $\left.{ }^{15-16-17}\right) ; \delta_{\mathrm{P}}\left(\mathrm{CDCl}_{3}\right)+37.76 ; \mathrm{m} / 2\left(\mathrm{HRMS}^{+}\right) 1138.191[\mathrm{M}+\mathrm{H}]^{+}\left(\mathrm{C}_{44} \mathrm{H}_{68}{ }^{79} \mathrm{Br}_{3} \mathrm{~N}_{7} \mathrm{O}_{7} \mathrm{P}_{3}\right.$ requires 1138.193).

Europium (III) complex of (S)-6,6',6'-(2-(4-(cyclohexanecarboxamido)butyl)-1,4,7triazacyclononane-1,4,7-triyl)tris(methylene)tris(4-bromopyridine-6,2diyl)tris(methylphosphinate), $\left[\right.$ Eu.L $\left.{ }^{1 b}\right]$

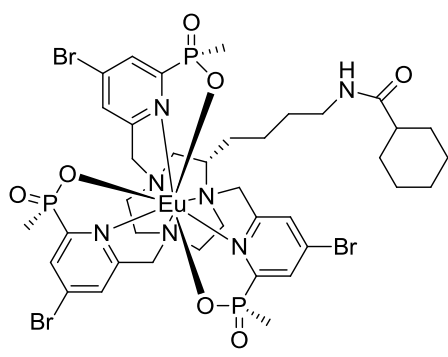

Triethyl 6,6',6"-((S)-2-(4-(cyclohexanecarboxamido)butyl)-1,4,7-triazacyclononane-1,4,7triyl)tris(methylene)tris(4-bromopyridine-6,2-diyl)tris(methylphosphinate) (10 mg, $8.8 \mu \mathrm{mol})$ was dissolved in $\mathrm{CD}_{3} \mathrm{OD}(3 \mathrm{~mL})$ and a solution of $0.1 \mathrm{M} \mathrm{NaOH}$ in $\mathrm{D}_{2} \mathrm{O}(1 \mathrm{~mL})$ was added. The mixture was heated to $90{ }^{\circ} \mathrm{C}$ under argon and monitored with ${ }^{31} \mathrm{P}-\mathrm{NMR}\left[\delta_{\mathrm{P}}(\right.$ reactant $)=$ 
$38.8,\left(\delta_{\mathrm{P}}(\right.$ product $\left.)=25.9\right]$. After $5 \mathrm{~h}$ the solution was cooled to RT and the $\mathrm{pH}$ was adjusted to 7 with $\mathrm{HCl}$. $\mathrm{Eu}(\mathrm{AcO}){ }_{3} \mathrm{H}_{2} \mathrm{O}(3.2 \mathrm{mg}, 9.7 \mu \mathrm{mol})$ was added and the mixture heated to $65^{\circ} \mathrm{C}$ overnight under argon. The solvent was removed under reduced pressure and the product purified by column chromatography (silica, $\mathrm{CH}_{2} \mathrm{Cl}_{2}: \mathrm{CH}_{3} \mathrm{OH}: \mathrm{NH}_{3} 9: 1$ : 0.1) giving the title compound as a white solid (5 mg, $50 \%) ; \delta_{\mathrm{P}}\left(\mathrm{CD}_{3} \mathrm{OD}\right) 43.4,40.7,37.5 ; \mathrm{m} / \mathrm{z}\left(\mathrm{HRMS}^{+}\right)$ $1203.995[\mathrm{M}+\mathrm{H}]^{+}\left(\mathrm{C}_{38} \mathrm{H}_{53}{ }^{79} \mathrm{Br}_{3}{ }^{153} \mathrm{EuN}_{7} \mathrm{O}_{7} \mathrm{P}_{3}\right.$ requires 1203.995); $R_{f}=0.32$ (silica, $\left.\mathrm{CH}_{2} \mathrm{Cl}_{2}: \mathrm{CH}_{3} \mathrm{OH}: \mathrm{NH}_{3}, 9: 1: 0.1(\mathrm{v} / \mathrm{v})\right)$.

Europium (III) complex of (S)-6,6',6"-(2-(4-(cyclohexanecarboxamido)butyl)-1,4,7triazacyclononane-1,4,7-triyl)tris(methylene)tris-4-[2-(2,4,6-trimethoxyphenyl)ethynyl]pyridin6,2-diyl)tris(methylphosphinate) $\left[\right.$ Eu.L $\left.^{6}\right]$

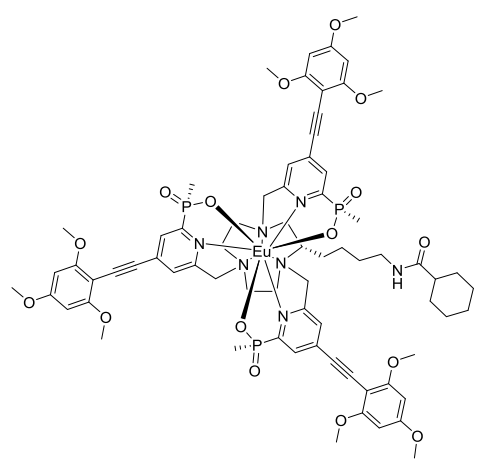

To a stirred degassed solution of the tris $p$-bromo Eu(III) complex [Eu. $\left.\mathbf{L}^{2}\right](0.6 \mathrm{mg}, 0.50 \mu \mathrm{mol})$ in a mixture of anhydrous THF/DMF (1:1 v/v, $400 \mathrm{~mL})$ was added 2,4,6-trimethoxyphenylacetylene $(0.3$ $\mathrm{mg}, 1.5 \mu \mathrm{mol})$ and triethylamine $(1.0 \mathrm{~mL}, 7.50 \mu \mathrm{mol})$, and the solution was degassed (freeze-thaw cycle) three times. [1,1-Bis(diphenylphosphino)ferrocene]dichloropalladium(II) (250 $\mu \mathrm{g}, 0.3 \mathrm{mmol})$ and $\mathrm{CuI}(60 \mu \mathrm{g}, 0.3 \mathrm{mmol})$ were added and the resulting yellow solution was stirred at $65{ }^{\circ} \mathrm{C}$ under argon for $12 \mathrm{~h}$. LC-MS analysis at this time revealed complete conversion of starting material. The solvent was removed under reduced pressure and the brown residue was purified by semi-preparative RP-HPLC [gradient: $50-100 \%$ methanol in water $\left(0.1 \%\right.$ formic acid) over $15 \mathrm{~min} ; \mathrm{t}_{R}=11.4 \mathrm{~min}$ ] to give $\left[\right.$ Eu. $\left.\mathbf{L}^{2}\right]$ as a white solid $(0.33 \mathrm{mg}, 51 \%)$; LRMS (ESI) $\mathrm{m} / z 1538[\mathrm{M}+\mathrm{H}]^{+}, 770[\mathrm{M}+2 \mathrm{H}]^{2+}$; $\left(\mathrm{HRMS}^{+}\right) \mathrm{m} / z \quad 769.7291\left[\mathrm{M}\left({ }^{153} \mathrm{Eu}\right)+2 \mathrm{H}\right]^{2+}\left(\mathrm{C}_{71} \mathrm{H}_{87} \mathrm{~N}_{7} \mathrm{O}_{16} \mathrm{P}_{3}{ }^{153} \mathrm{Eu}\right.$ requires 769.7322$) ; \tau_{M e O H}=1.05$ $\mathrm{ms} ; \Phi_{M \text { e } \mathrm{o}}^{e m} 55( \pm 15) \% ; \Phi_{H 2 O}^{e m}=10( \pm 15) \% ; \varepsilon_{\mathrm{MeOH}}(355 \mathrm{~nm})=55,100 \mathrm{M}^{-1} \mathrm{~cm}^{-1}$.

\section{References}


1. K. J. Arm and J. A. G. Williams, Chem. Commun., 2005, 232.

2. V. L. Whittle and J. A. G. Williams, Dalton Trans., 2009, 3929.

3. a) L. S. Natrajan, A. J. L. Villaraza, A. M. Kenwright and S. Faulkner, Chem. Commun., 2009, 6020; b) S. J. Pope and S. Faulkner, J. Am. Chem. Soc., 2003, 125, 10526.

4. L. Tei, G. Giugliotta, S. Avedano, G. B. Giovenzana and M. Botta, Org. Biomol. Chem., 2009, 7, 4406.

5. T. J. Sorensen, M. Tropiano, O. A. Blackburn, J. A. Tilney, A. M. Kenwright and S. Faulkner, Chem. Commun., 2013, 49, 783.

6. a) M. S. Tremblay and D. S. Sames, Chem. Commun. 2006, 4116; b) E. Pershagen, J. Nordholm, K. E. Borbas, J. Am. Chem. Soc., 2012, 134, 9832; c) C. Szijjarto, E. Pershagen, K. E. Borbas, Dalton Trans., 2012, 41, 7660.

7. D. A. Fulton, M. O’Halloran, D. Parker, K. Senanayake, M. Botta and S. Aime, Chem. Commun., 2005, 474.

8. D. A. Fulton, E. M. Elemento, S. Aime, L. Chaabane, M. Botta and D. Parker, Chem. Commun. 2006, 1064.

9. a) E. B Debroye, G. Dehaen, S. Eliseeva, S. Laurent, L. vander Elst, R. N. Muller, K. Binnemanns and T.N. Parac-Vogt, Dalton Trans. 2012, 41, 10159; b) P. Verwilst, S. V. Eliseeva, L. vander Elst, C. Burtea, S. Laurent, S. Petoud, R. N. Muller, T. N. Parac-Vogt, W. M. Borggraeve, Inorg. Chem. 2012, 51, 6405.

10. J. B. Livramento, A. Sour, A. Borel, A. E. Merbach and E. Toth, Chemistry-Eur. J. 2006, 12, 989.

11. a) C. P. Montgomery, E. J. New, R. Pal and D. Parker, Acc. Chem. Res., 2009, 42, 925; b) R. Pal, D. Parker and L. C. Costello, Org. Biomol. Chem. 2009, 7, 1525; c) E. J. New, D. Parker, D. G. Smith and J. W. Walton, Curr. Opin. Chem. Biol., 2010, 14, 238; d) E. J. New, A. Congreve and D. Parker, Chem. Sci., 2010, 1, 111; e) S. Mohandessi, M. Rajendran, D. Magda and L. W. Miller, Chemistry-Eur. J., 2012, 18, 10825.

12. J. W. Walton, A. Bourdolle, S. J. Butler, M. Soulie, M. Delbianco, B. K. McMahon, R. Pal, H. Puschmann, J. M. Zwier, L. Lamarque, O. Maury, C. Andraud and D. Parker, Chem. Commun. 2013, 49, 1600.

13. S. J. Butler, L. Lamarque, R. Pal and D. Parker, Chem. Sci., 2014, 5, in press, DOI:10.1039/C3SC53056F.

14. S. J. Butler and D. Parker, Chem. Soc. Rev. 2013, 42, 1652; b) S. V. Eliseeva and J-C. G. Bunzli, Chem. Soc. Rev., 2010, 39, 189; c) A. Thibon and V. C. Pierre, Anal. Bioanal. Chem., 2009, 394, 107.

15. C. Song, Z. Ye, G. Wang, J. Yuan and Y. Guan, Chemistry-Eur. J., 2010, 16, 6464. 
16. J. M. Zwier, H. Bazin, L. Lamarque and G. Mathis, Inorg. Chem. 2014, 53, in press; DOI: 10.1021/ic402234k.

17. Q. Wang, K. N. Nono, M. Syrjanpaa, L. J. Charbonniere, J. Hovinen and H. Harma, Inorg. Chem. 2013, 52, 8461.

18. A. Picot, A. D’Aleo, P. L. Baldeck, A. Grichine, A. Duperray, C. Andraud and O. Maury, J. Am. Chem. Soc., 2008, 130, 1532.

19. A. J. Palmer, S. H. Ford, S. J. Butler, T. J. Hawkins, P. J. Hussey, R. Pal, D. Parker and J. W. Walton, RSC Advances, 2014, in press; DOI:10.1039/C3RA45426F.

20. J. E. Hein and V. V. Fokin, Chem. Soc. Rev., 2010, 39, 1302-1315.

21. Z. E. Charmas, X. M. Guo, J.-L. Canet, A. Gautier, D. Boyer and R. Mahiou, Dalton Trans., 2010, 39, 7091.

22. C. S. Bonnet, F. Buron, F. Caille, C. M. Shade, B. Drahos, L. Pellegatti, J. Zhang, S. Villette, L. Helm, C. Pichon, F. Suzenet, S. Petoud and E. Toth, Chemistry - Eur. J., 2012, 18, 1419.

23. N. H. Evans, R. Carr, M. Delbianco, R. Pal, D. Parker and D. S. Yufit, Dalton Trans., 2013, 42, 15610 .

24. J. W. Walton, L. Di Bari, D. Parker, G. Pescitelli, H. Puschmann and D. S. Yufit, Chem. Commun., 2011, 47, 12289.

25. a) G. Muller, Dalton Trans., 2009, 9692; (b) R. Carr, N. H. Evans and D. Parker, Chem. Soc. Rev., 2012, 41, 7673.

26. K. L. Gempf, S. J. Butler, A. M. Funk and D. Parker, Chem. Commun. 2013, 49, 9104.

27. a) A.S. Craig, I.M. Helps, K.J. Jankowski, D. Parker, N. R. A. Beeley, B. A. Boyce, M.A.W. Eaton, A.T. Millican, K. Millar, A. Phipps, S.K. Rhind, A. Harrison and C. Walker J. Chem. Soc., Chem. Commun. 1989, 794; b) J.P.L. Cox, A.S. Craig, I.M. Helps, K.J. Jankowski, D. Parker, M.A.W. Eaton, A.T. Millican, K. Millar, N.R.A. Beeley and B.A. Boyce, J. Chem. Soc., Perkin Trans I, 1990, 2567.

28. a) V. R. Pallela, M. R. Mallireddigari, S. C. Cosenza, B. Akula, D. R. C. V. Subbaiah, E. P. Reddy and M. V. R. Reddy, Org. Biomol. Chem., 2013, 11, 1964; b) N. J. Lawrence, F. A. Ghani, L. A. Hepworth, J. A. Hadfield, A. T. McGown, R. G. Pritchard, Synthesis, 1999, 1656.

29. G. M. Sheldrick, Acta Cryst., Sect. A: 2008, 64, 112.

30. O.V.Dolomanov, L.J.Bourhis, R.J.Gildea, J.A.K.Howard, H.Puschmann, J.Appl.Cryst., 2009, 42, 339 . 